\title{
Pengaruh Kepemimpinan Transformasional dan Lingkungan Kerja Non Fisik terhadaap Kinerja Melalui Organizational Citizenship Behavior sebagai Variabel Intervening
}

\author{
Talia Cindrakasih", Siti Nur Azizah ${ }^{2}$ \\ ${ }^{1}$ Sekolah Tinggi Ilmu Ekonomi Putra Bangsa \\ 2Sekolah Tinggi Ilmu Ekonomi Putra Bangsa \\ Email: taliacindrakasih@gmail.com
}

\section{ARTICLE INFO}

Article History:

Received: March $13^{\text {th }} 2020$

Accepted: March 14th 2020

Published: June 30th 2020

Keywords:

Lingkungan Kerja Non

Fisik, Organizational

Citizenship Behavior,

Kinerja, Kepemimpinan

Transformasional

\begin{abstract}
Penelitian ini bertujuan untuk menganalisis kinerja guru pada guru SMK Cipta Karya Prembun. Penelitian ini menggunakan variabel kepemimpinan transformasional, lingkungan kerja non fisik dan Organizational Citizenship Behavior (OCB) untuk menganalisis kinerja guru di SMK Cipta Karya Prembun. Selain itu penelitian ini menggunakan variabel OCB sebagai variabel intervening terhadap kinerja guru di SMK Cipta Karya Prembun. Variabel dalam penelitian ini adalah kepemimpinan transformasional, lingkungan kerja non fisik, OCB dan kinerja. Populasi dalam penelitian ini adalah seluruh guru di SMK Cipta Karya Prembun yang berjumlah 32 guru. Teknik pengambilan sampel adalah sampel jenuh karena jumlah responden yang relatif kecil sehingga jumlah seluruh populasi digunakan sebagai sampel. Teknik pengumpulan data menggunakan kuesioner. Analisis data yang digunakan adalah uji instrumen validitas dan reliabilitas, uji asumsi klasik, uji hipotesis, analisis korelasi, analisis jalur dan uji sobel. Alat bantu pengolahan data menggunakan SPSS for windows versi 22 dan sobel kalkulator. Hasil penelitian ini menunjukan bahwa kepemimpinan transformasional tidak berpengaruh terhadap OCB dan kinerja. Lingkungan kerja non fisik berpengaruh positif dan signifikan terhadap OCB. Lingkungan kerja non fisik berpengaruh positif dan signifikan terhadap kinerja. OCB berpengaruh positif dan signifikan terhadap Kinerja.
\end{abstract}

\section{Pendahuluan}

Keberhasilan suatu organisasi ditentukan oleh faktor manusia atau karyawan dalam mencapai tujuannya. Menciptakan sumber daya manusia yang handal membutuhkan pengelolaan yang baik agar kinerja lebih optimal. Guru merupakan salah satu sumber daya manusia di sekolah. Kinerja guru di sekolah mempunyai peran penting dalam pencapaian tujuan sekolah (Sampurno, 2015). Peningkatan kinerja merupakan upaya untuk mencapai tujuan organisasi, karena kinerja merupakan perilaku nyata yang ditampilkan setiap orang sebagai prestasi kerja yang dihasilkan oleh pegawai sesuai dengan perannya dalam organisasi. 
Kinerja adalah hasil kerja secara kualitas dan kuantitas yang dicapai oleh seorang karyawan dalam melaksanakan tugasnya sesuai dengan tanggung jawab yang diberikan kepadanya (Mangkunegara, 2001). SMK Cipta Karya Prembun berhasil meluluskan 100\% siswanya dalam 3 tahun terakhir. Keberhasilan tersebut merupakan hasil dari kinerja yang optimal dari guru. kinerja yang optimal karena rekan kerja yang tanggap membantu, meski bukan tugasnya. Sikap tersebut disebut Organizational Citizenship Behavior (OCB). Banyaknya aktivitas yang dilakukan oleh guru-guru dibutuhkan suatu perilaku ekstra peran untuk menjalankan semua aktivitas tersebut sehingga organisasi menjadi lebih efektif. Perilaku OCB dilakukan ketika tugas yang dimiliki telah selesai.

Faktor lain yang diduga mempengaruhi kinerja adalah kepemimpinan transformasional. Berkembangnya semangat kerja, kerja sama yang harmonis, minat terhadap perkembangan kualitas pendidikan, suasana kerja yang menyenangkan serta perkembangan kualitas profesional guru banyak ditentukan oleh kualitas kepemimpinan oleh kepala sekolah (Handayani, 2015). Kepala sekolah melakukan usaha untuk mengubah kesadaran dan meningkatkan semangat kerja guru di SMK Cipta Karya Prembun demi tercapainya visi organisasi. Kepala sekolah berupaya meningkatkan kinerja guru dengan memberikan dorongan dan semangat kerja yang tinggi untuk meningkatkan kinerja.

Guru di SMK Cipta Karya Prembun memiliki hubungan yang harmonis antara satu sama lain. Saling bekerjasama dalam menyelesaikan pekerjaan dalam upaya pencapaian tujuan organisasi. Perilaku tersebut merupakan bagian dari lingkungan kerja non fisik. Komunikasi yang baik terjalin antar guru, supaya tidak salah paham. Dukungan dari lingkungan kerja yang kondusif akan meningkatkan kinerja.

\section{Kajian Teori dan Telaah Literatur}

\section{Kinerja}

Kinerja (prestasi kerja) adalah hasil kerja yang baik berdasarkan kualitas maupun kuantitas yang dicapai oleh seseorang dalam melaksanakan tugas sesuai dengan tanggung jawab yang diberikan (Mangkunegara, 2007).

Adapun indikator penilaian terhadap kinerja menurut Rivai dan Basri (2013): (1) Quantity of work, (2) Quality of work, (3) Job knowledge, (4) Creativeness, (5) Coorperation, (6) Dependability, (7) Intiative, dan (8) Personal qualities.

\section{Organizational citizenship behavior}

Organ (1988) dalam Luthans (2006), mendefinisikan Organizational Citizenship Behavior (OCB) sebagai perilaku individu yang bebas memilih, tidak teratur secara langsung atau eksplisit oleh sistem penghargaan formal, dan secara bertingkat mempromosikan fungsi organisasi yang efektif. Menurut Organ (2006) mengidentifikasikan perilaku OCB dibangun dari lima indikator, yaitu: (1) Altruisme, (2) Conscientiousness, (3) Sportmanship, (4) Courtesy dan (5) Civic Virtue.

\section{Kepemimpinan transformasional}

Kepemimpinan transformasional adalah kemampuan pemimpin mengubah motivasi kerja, pola kerja dan nilai-nilai kerja yang persepsikan bawahan sehingga mereka mampu mengoptimalkan kinerja untuk mencapai tujuan organisasi, Bass dalam Adinata (2016). Terdapat empat indikator kepemimpinan transformasional menurut Robbins dan Judge (2008), yaitu: (1) Pengaruh Ideal (Idealized Influence), (2) Motivasi Inspirational (Inspirational 
Motivation), (3) Stimulasi Intelektual (Intellectual Stimulation), (4) Pertimbangan Individual (Individualized Consideration).

\section{Lingkungan kerja non fisik}

Lingkungan kerja non fisik merupakan kelompok lingkungan kerja yang tidak bisa diabaikan. Lingkungan kerja non fisik adalah semua keadaan yang terjadi yang berkaitan dengan hubungan sesama rekan kerja ataupun hubungan dengan bawahan (Sedarmayanti, 2011). Adapun indikator untuk mengukur lingkungan kerja non fisik menurut DeStefano (2006): (1) Prosedur kerja, (2) Standar kerja, (3) Pertanggung jawaban supervisor, (4) Kejelasan tugas, (5) Sistem penghargaan dan (6) Hubungan antar karyawan.

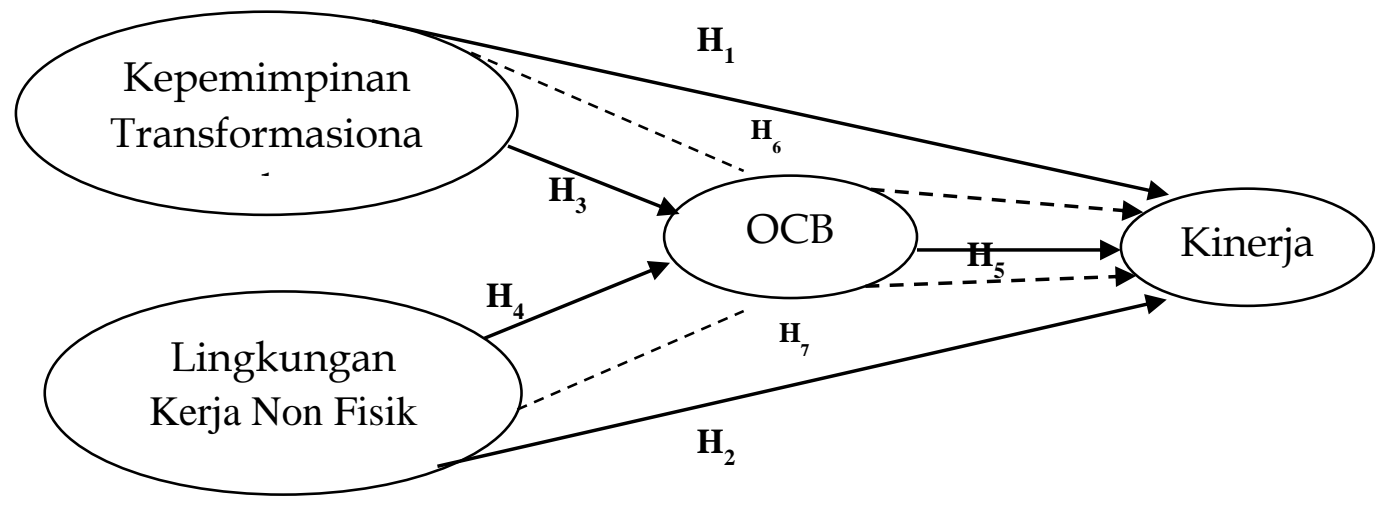

Gambar 1. Model penelitian

\section{Metode Penelitian}

Sampel dalam penelitian ini adalah guru di SMK Cipta Karya Prembun sejumlah 32 orang. Teknik pengumpulan data menggunakan observasi, wawancara, studi pustaka dan kuesioner. Alat bantu yang digunakan dalam pengolahan data yaitu Program SPSS 22 For Windows. Sementara teknik analisisnya menggunakan 2 (dua) cara yaitu analisis deskriptif dan analisis statistik. Analisis statistik meliputi: uji validitas, uji reliabilitas, uji asumsi klasik, uji hipotesis, analisis korelasi, analisis jalur dan sobel test.

\section{Hasil dan Pembahasan}

\section{Pengaruh kepemimpinan transformasional terhadap OCB}

Pengujian hipotesis pertama bertujuan untuk mengetahui pengaruh variabel kepemimpinan transformasional terhadap OCB. Hasil penelitian ini menunjukan bahwa kepemimpinan transformasional tidak memiliki pengaruh terhadap OCB pada Guru di SMK Cipta Karya Prembun yang ditunjukan dari nilai thitung sebesar 1,997<2,04227. Kepemimpinan transformasional tidak memiliki pengaruh tehadap OCB di SMK Cipta Karya Prembun. Tinggi rendahnya perilaku berperan ekstra atau OCB tidak dipengaruhi oleh faktor pemimpinnya. Penelitian ini sejalan dengan penelitian yang dilakukan oleh Purwaningsih dkk., yang menyatakan bahwa kepemimpinan transformasional tidak berpengaruh terhadap OCB. Gaya kepemimpinan kepala sekolah di SMK Cipta Karya Prembun tidak mampu mempengaruhi tingkat OCB guru, itu berarti perilaku pemimpin kurang memberi dampak pada guru untuk berperilaku OCB. 


\section{Pengaruh lingkungan kerja non fisik terhadap $O C B$}

Pengujian hipotesis kedua betujuan untuk mengetahui pengaruh lingkungan kerja non fisik terhadap OCB. Hasil penelitian ini menunjukan bahwa lingkungan kerja non fisik memiliki pengaruh signifikan terhadap OCB pada Guru di SMK Cipta Karya Prembun yang ditunjukan dari nilai $t_{\text {hitung }}>t_{\text {tabel }}$ yaitu sebesar 5,263>2,04227 dan nilai signifikan sebesar $0,000<0,05$. Dari hasil tersebut menyatakan bahwa variabel lingkungan kerja non fisik mempunyai pengaruh signifikan dan positif terhadap OCB pada Guru di SMK Cipta Karya Prembun. Pengaruh lingkungan kerja non fisik yang signifikan terhadap OCB mengidentifikasi bahwa tinggi rendahnya lingkungan kerja non fisik pada Guru di SMK Cipta Karya Prembun mempengaruhi tinggi rendahnya OCB. Rekan kerja yang saling membantu mengoptimalkan kinerja dalam upaya pencapaian tujuan organisasi.

\section{Pengaruh kepemimpinan transformasional terhadap kinerja}

Pengujian hipotesis ketiga bertujuan untuk mengetahui pengaruh variabel kepemimpinan transformasional terhadap kinerja. Hasil penelitian ini menunjukan bahwa kepemimpinan transformasional tidak memiliki pengaruh terhadap kinerja pada Guru di SMK Cipta Karya

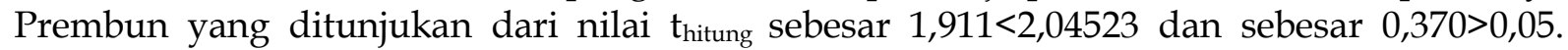
Hasil ini menyatakan bahwa variabel kepemimpinan transformasional tidak mempunyai pengaruh terhadap kinerja pada Guru di SMK Cipta Karya Prembun. Tinggi rendahnya perilaku kinerja guru tidak dipengaruhi oleh faktor pemimpinnya. Hasil penelitian ini tidak sejalan dengan penelitian yang dilakukan oleh Rustamji, dkk. yang menyatakan bahwa kepemimpinan transformasional berpengaruh terhadap OCB, namun sejalan dengan hasil penelitian yang dilakukan oleh Cahyono dkk. Hasil penelitian Cahyono dkk., menyatakan bahwa kepemimpinan transformasional tidak berpengaruh terhadap kinerja.

\section{Pengaruh lingkungan kerja non fisik terhadap kinerja}

Pengujian hipotesis keempat betujuan untuk mengetahui pengaruh lingkungan kerja non fisik terhadap kinerja. Hasil penelitian ini menunjukan bahwa lingkungan kerja non fisik memiliki pengaruh signifikan terhadap kinerja pada Guru di SMK Cipta Karya Prembun yang ditunjukan dari nilai $t_{\text {hitung }}>t_{\text {tabel }}$ yaitu sebesar 2,343 $>2,04523$ dan nilai signifikan sebesar $0,026<0,05$. Dari hasil tersebut menyatakan bahwa variabel lingkungan kerja non fisik mempunyai pengaruh signifikan dan positif terhadap kinerja pada Guru di SMK Cipta Karya Prembun. Pengaruh lingkungan kerja non fisik yang signifikan terhadap kinerja mengidentifikasi bahwa tinggi rendahnya lingkungan kerja non fisik pada Guru di SMK Cipta Karya Prembun mempengaruhi tinggi rendahnya kinerja. Lingkungan kerja non fisik di SMK Cipta Karya Prembun mampu meningkatkan kinerja guru yang optimal.

\section{Pengaruh OCB terhadap Kinerja}

Pengujian hipotesis kelima betujuan untuk mengetahui pengaruh OCB terhadap kinerja. Hasil penelitian ini menunjukan bahwa OCB memiliki pengaruh signifikan terhadap kinerja pada Guru di SMK Cipta Karya Prembun yang ditunjukan dari nilai $t_{\text {hitung }}>t_{\text {tabel }}$ yaitu sebesar $2,106>2,04523$ dan nilai signifikan sebesar 0,044<0,05. Dari hasil tersebut menyatakan bahwa variabel OCB mempunyai pengaruh signifikan dan positif terhadap kinerja pada Guru di SMK Cipta Karya Prembun. Pengaruh OCB yang signifikan terhadap kinerja mengidentifikasi bahwa tinggi rendahnya OCB pada Guru di SMK Cipta Karya Prembun mempengaruhi tinggi rendahnya kinerja. Perilaku OCB bisa mengoptimalkan kinerja, guru di SMK Cipta Karya Prembun bersedia berperan ekstra untuk menghasilkan kinerja yang optimal. 


\section{Pengaruh kepemimpinan transformasional terhadap kinerja melalui OCB}

Pengujian hipotesis keenam bertujuan untuk mengetahui pengaruh variabel kepemimpinan transformasional terhadap kinerja melalui OCB. Berdasarkan hasil analisis jalur diketahui pengaruh langsung yang diberikan kepemimpinan transformasional terhadap kinerja sebesar $-0,911$. Pengaruh tidak langsung kepemimpinan transformasional terhadap kinerja melalui OCB yaitu 1,997×2,106 = 4,205682 dan pengaruh totalnya adalah 1,997+2,106=4,103. Berdasarkan hasil perhitungan tersebut dapat diketahui bahwa nilai pengaruh tidak langsung $(4,205682)$ lebih besar dibanding pengaruh langsung $(-0,911)$. Hal ini menunjukan bahwa secara tidak langsung kepemimpinan transformasional melalui OCB mempunyai pengaruh signifikan terhadap kinrja pada gurudi SMK Cipta Karya Prembun. Berdasarkan hasil uji yang digunakan dengan kalkulator sobel menunjukan bahwa test statistic $<\mathrm{t}_{\text {tabel }}$ yaitu $1,44601022<2,04227$ dan $p$-value $>$ a yaitu $0,14817434>0,05$. Hasil perhitungan tersebut menunjukan bahwa OCB tidak dapat memediasi antara variabel kepemimpinan transformasional terhadap kinerja pada guru di SMK Cipta Karya Prembun.

\section{Pengaruh lingkungan kerja non fisik terhadap kinerja melalui OCB}

Pengujian hipotesis ketujuh bertujuan untuk mengetahui pengaruh variabel lingkungan kerja non fisik terhadap kinerja melalui OCB. Berdasarkan hasil analisis jalur diketahui pengaruh langsung yang diberikan lingkungan kerja non fisik terhadap kinerja sebesar 2,343. Pengaruh tidak langsung lingkungan kerja non fisik terhadap kinerja melalui OCB yaitu $5,263 \times 2,106=11,08388$ dan pengaruh totalnya adalah $5,263+2,106=7,369$. Berdasarkan hasil perhitungan tersebut dapat diketahui bahwa nilai pengaruh tidak langsung $(11,08388)$ lebih besar dibanding pengaruh langsung $(2,343)$. Hal ini menunjukan bahwa secara tidak langsung lingkungan kerja non fisik melalui OCB mempunyai pengaruh signifikan terhadap kinerja pada guru di SMK Cipta Karya Prembun. Berdasarkan hasil uji yang digunakan dengan kalkulator sobel menunjukan bahwa test statistic $<\mathrm{t}_{\text {tabel }}$ yaitu 0,14817434<2,04227 dan p-value $>$ a yaitu $0,05092386>0,05$. Hasil perhitungan tersebut menunjukan bahwa OCB tidak dapat memediasi antara variabel lingkungan kerja non fisik terhadap kinerja pada guru di SMK Cipta Karya Prembun.

\section{Penutup dan Saran}

Lingkungan kerja non fisik menjadi variabel yang berpengaruh signifikan terhadap OCB pada guru di SMK Cipta Karya Prembun. Maka, untuk meningkatkan OCB perlu untuk membentuk lingkungan kerja non fisik yang baik. Lingkungan kerja yang baik yaitu seperti terjalinnya komunikasi, perilaku saling tolong menolong antar satu sama lain, serta membentuk lingkungan kerja yang nyaman dalam menjalin kerja sama. Komunikasi yang baik antar satu sama lain merupakan salah satu bentuk lingkungan kerja non fisik, ketika suatu pekerjaan dikomunikasikan dengan baik akan memudahkan satu sama lain untuk membantu pekerjaan yang ada. Guru bekerjasama dan saling tolong-menolong dengan berperan ekstra dalam menyelesaikan pekerjaan, akan membuat tujuan-tujuan organisasi akan terwujud.

Lingkungan kerja non fisik menjadi variabel yang mampu mempengaruhi kinerja guru di SMK Cipta Karya Prembun. Terjalinnya lingkungan kerja yang harmonis menjadikan guru merasa nyaman dan mampu mengoptimalkan kinerjanya. Jika guru merasa nyaman dengan lingkungan kerja yang dibentuk maka kinerja yang dihasilkan akan meningkat. Lingkungan kerja yang nyaman membuat guru merasa betah berada di lingkungan kerjanya sehingga ketika dalam menjalankan pekerjaannya guru akan bekerja dengan optimal. Guru akan merasa jenuh jika lingkung kerja non fisiknya tidak membuat nyaman dalam bekerja. 
Sehingga, menciptakan lingkungan kerja yang harmonis merupakan upaya dalam meningkatkan kinerja guru di SMK Cipta Karya Prembun.

OCB menjadi variabel yang mampu mempengaruhi kinerja guru di SMK Cipta Karya Prembun. Sehingga, ketika OCB meningkat maka kinerja guru meningkat. Perilaku berperan ekstra mampu mempengaruhi tingkat kinerja guru di SMK Cipta Karya Prembun. OCB memberi kontribusi pada organisasi berupa peningkatan produktivitas manajer, menghemat sumber daya yang dimiliki manajemen dan organisasi secara keseluruhan, membantu memelihara fungsi kelompok menjadi sangat efektif.

\section{Referenasi}

Adinata, U. W. S. (2016). Pengaruh Kepemimpinan Transformasional, Motivasi, dan Budaya Organisasi terhadap Kinerja Karyawan KJKS BMT Tamzis Bandung. Jurnal Ekonomi, Bisnis E Entrepreneurship, 9(2), 136-157.

DeStefano, T. J., Henry, C., Megan G., \& Thomas P. (2006). The Relationship between Work Environment Factors and Job Satisfaction Among Rural Behavioral Health Professionals. Journal of Rural Community Psycology, 1(2), 123-127.

Handayani, T., \& Rasyid, A. A. (2015). Pengaruh kepemimpinan kepala sekolah, motivasi guru, dan budaya organisasi terhadap kinerja guru SMA negeri Wonosobo. Jurnal Akuntabilitas Manajemen Pendidikan, 3(2), 264-277.

Luthans, F. (2006). Perilaku Organisasi. Edisi Sepuluh. Yogyakarta: PT. Andi.

Mangkunegara, A. P. (2001). Manajemen Sumber Daya Manusia Perusahaan. Cetakan Ketiga. Bandung: PT. Remaja Rosdakarya Offset.

Mangkunegara, A. P. (2007). Manajemen Sumber Daya Manusia. Cetakan Ketujuh. Bandung: PT. Remaja Rosdakarya Offset.

Organ, D. W. (2006). Organizational Citizenship Behavior: The Good Soldier Syndrome. Lexington, MA: Lexington Books.

Rivai, V., \& Basri, A. F. M. (2013). Manajemen Sumber Daya Manusia Untuk Perusahaan. Cetakan Pertama. Jakarta: Raja Grafindo Persada.

Robbins, S. P., \& Judge T. A. (2008). Perilaku Organisasi (Organizational Behavior). Edisi Keduabelas. Jakarta: Salemba Empat.

Sampurno, D., \& Wibowo, A. (2015). Kepemimpinan Kepala Sekolah, Lingkungan Kerja, Motivasi Kerja, dan Kinerja Guru di SMK Negeri 4 Pandeglang. Jurnal Pendidikan Ekonomi Dan Bisnis (JPEB), 3(2), 165-180.

Sedarmayanti. (2001). Sumber Daya Manusia dan Produktivitas Kerja. Bandung: Mandar Maju. 